European journal of American studies

\title{
Eleanor Roosevelt and Diplomacy in the Public Interest
}

Anya Luscombe and Dario Fazzi

\section{OpenEdition}

\section{Journals}

Electronic version

URL: https://journals.openedition.org/ejas/11890

DOI: $10.4000 /$ ejas. 11890

ISSN: 1991-9336

Publisher

European Association for American Studies

Electronic reference

Anya Luscombe and Dario Fazzi, "Eleanor Roosevelt and Diplomacy in the Public Interest", European journal of American studies [Online], 12-1 | 2017, document 1, Online since 07 March 2017, connection on 08 July 2021. URL: http://journals.openedition.org/ejas/11890 ; DOl: https://doi.org/10.4000/ejas 11890

This text was automatically generated on 8 July 2021.

Creative Commons License 


\title{
Eleanor Roosevelt and Diplomacy in the Public Interest
}

\author{
Anya Luscombe and Dario Fazzi
}

1 Recent scholarly production on transatlantic relations in Europe is greatly interested in the role that social and cultural, not just political and diplomatic encounters, exchanges, and interconnections played in the shaping of the EuroAmerican relations. ${ }^{i}$ As a consequence, this trend avows the absolute necessity of adopting a broader multidisciplinary approach so as to overcome the ideological dispute between cultural imperialism and cultural transmission in the transatlantic arena.

2 Through such a multidisciplinary approach it is possible to highlight that, being the transatlantic exchanges characterized either by fair interactions or by hegemonic ends, they have nevertheless been participated and molded by a plurality of non-state actors, whose significance can be differently weighed but hardly denied. This begs the question of what has been the role, within this process of cultural exchanges, of those leading individuals who, due to their baggage of personal experience, their intellectual wisdom, and their public prominence, have been able to leave their enduring imprint on the transatlantic relations as a whole. Scholarship tends now to recognize such individuals as actors of cultural diplomacy, or, more generally, as public diplomats. And, if it is true that, as the U.S. Department of State officials argue, cultural diplomacy is "the lynchpin of public diplomacy...[that] reveals the soul of a nation,"Eleanor Roosevelt might rightly deserve a mention apart as someone who greatly contributed to the revelation of that soul.ii

3 In April 1952, U.S. Secretary of State, Dean Acheson, wrote to President Truman expressing his admiration for Eleanor Roosevelt's contribution to the United States government's aims and praised her "effectiveness as a negotiator" while on her journey through the Middle East and Southeast Asia: "She was received everywhere with great cordiality except in the Arab states... Although it was undertaken in a purely unofficial capacity, Mrs. Roosevelt's journey has served the public interest exceedingly well." ${ }_{\text {iii }}$ At the time of the visit to which Acheson refers, Mrs. Roosevelt represented the U.S. at the 
United Nations, she had been actively engaged in a variety of politically and socially relevant activities to serve the public interest for more than three decades and would continue to be so for another ten years after. She campaigned for the rights of women, children and minorities. In public utterances she encouraged people to take an active interest in politics, to contribute towards the achievement of peace. Her astute perception of the vital role the media played, enabled her to use various communication methods (columns, books, speeches, radio and television) to educate the general public and aim at creating a shared identity, both in the US and between the US and other countries, most notably transatlantic allies.

4 Her role in promoting the public interest started well before she became First Lady. In the 1920s already she played an instrumental role in formal bodies such as the League of Women Voters, the Women's Trades Union League, the Women's Division of the Democratic party, but also informally in her teaching at the Todhunter School for girls, the charity work in the tenements of New York City, her visits around the country meeting ordinary folk and her work as a journalist and commentator. As a First Lady, she was outspoken on civil rights, a staunch supporter of the New Deal, urged FDR to appoint women to his cabinet and counseled the American public about the need to oppose fascism. The Roosevelts were a political team that not only helped America through the Great Depression, but also the world through the Second World War. As Winston Churchill said at the Pilgrim's Dinner in 1948, FDR could not have been the President he was without Eleanor Roosevelt:

5 Many of us know what we hold to our wives in life's varied journey. Mrs. Roosevelt has made her distinctive and personal contribution the generous thought of modern society...tonight we must ascribe to Mrs. Roosevelt the marvelous fact that a crippled man, the victim of a cruel affliction was able for more than ten years to ride the storms of peace and war at the summit of the United States ....and the debt we owe to President Roosevelt is also owed to her. iv $^{\text {th }}$

6 Following FDR's death Mrs. Roosevelt came into her own ${ }^{\mathrm{v}}$ when she was appointed a delegate to the newly-formed United Nations and was elected as Chairman of its Human Rights Commission where she was the driving force behind the acceptance of the Universal Declaration of Human Rights. This document remains to this day "the touchstone of the global Human Rights movement and a key component of an international system that provides for international scrutiny of the way in which a nation treats its citizens."vi As a delegate to the UN's Third Committee (Social, Humanitarian and Cultural Affairs), Eleanor Roosevelt spoke out in support of European refugees who did not want to return to their country of origin. She "possessed not only a passionate commitment to human rights, but a hard-earned knowledge of the political and cultural obstacles to securing them in a divided world." vii

7 This special edition of the European Journal of American Studies aims to examine the way Eleanor Roosevelt gained knowledge of such obstacles and some of the ways in which she used public diplomacy to secure the freedoms she fervently believed people everywhere in the world were entitled to. Her efforts in this regard fall within the many forms of formal and informal diplomacy that constitute as much a part of transatlantic relations as do military planning, state diplomacy, and economic 
initiatives. ${ }^{\text {viii }}$ Indeed, as the different chapters will show, the former American First Lady can be firmly placed amongst the most influential American public diplomats of the twentieth century and will argue that American cultural diplomacy throughout the world benefited from her activities.

8 The first essay in this collection looks at how Eleanor Roosevelt contributed to the shaping of American pacifism in the years between the two world wars. Dario Fazzi argues that Mrs. Roosevelt's vision of peace was proactive and pragmatic, defending and promoting international peace, but not pacifism at all costs. The type of pacifism she augured for, therefore, was a truly modern one and enabled her to transform her humanitarian activism into a powerful political force within the administration, substantially changing the image and perception of the U.S. first lady at home and abroad. This in turn, Fazzi asserts, boosted Eleanor Roosevelt's social involvement and made her public attitudes more assertive.

9 As well as auguring for international peace, Eleanor Roosevelt was heavily involved in trying to attain domestic peace between the white and black communities. In particular, in the 1930s she vigorously supported attempts to outlaw lynching. In essay number two, Melissa Cooper turns her attention to this aspect of Eleanor Roosevelt's diplomacy. Cooper situates FDR's inaction on supporting the Costigan-Wagner antilynching bill within the administration's so-called 'war on crime', meaning he wanted the federal government to take responsibility for tackling lynching, rather than merely a need on his behalf to avoid southern states blocking his New Deal reforms. Eleanor Roosevelt, Cooper asserts, failed to make clear to the NAACP, and its Executive Secretary Walter White in particular, where FDR really stood on the matter and in doing so, falsely gave hope to the NAACP that the administration would support the bill and consequently soured relations between the civil rights movement and the government.

10 The focus of the third essay is women's rights and intercultural understanding as can be gleaned from the works of Eleanor Roosevelt and Dutch travel journalist, Mary Pos, in the period 1930s-1950s. Pos attended ER press conferences at the White House in 1937 and in the Netherlands in 1950. Babs Boter draws on the diaries, correspondence, and lecture notes of Pos and publications by Eleanor Roosevelt to investigate the similarities and differences in the way the two women negotiated what she calls the transnational and gendered arena of journalism of the time. According to Boter, while both women advocated strongly for better intercultural communication, Pos was not always an admirer of Mrs. Roosevelt's approach to shaping transatlantic relations 'from below'.

11 When FDR died in April 1945, Eleanor Roosevelt was faced with a choice: retiring quietly, carrying on with a few projects close to her heart or developing a new political career of her own. Despite her concerns about her capabilities, she agreed to Harry Truman's request for her to become an American delegate to the United Nations - a way to continue her husband's legacy. Here at the UN, Eleanor Roosevelt could work internationally on many of the issues like women's rights, social and economic rights and peace that she had augured so hard for in the US during the previous decades. She could also work on promoting the image of America and American values abroad, which included the vital role she felt the arts could play in fostering transatlantic relations. 
${ }_{12}$ Camelia Lenart considers Eleanor Roosevelt's involvement in the inception of American cultural diplomacy by focusing on the special collaboration between her and the American dance pioneer Martha Graham. Lenart views the patronage of Graham's performances of modernism and patriotism as a conscientious decision by ER to use the arts in the service of politics and diplomacy. Eleanor Roosevelt used her prestige and connections to help Graham during her tours in Europe in the early 1950s, bringing the American ambassador to France with her when attending the dancer's first European tour in 1950 and introducing Graham to Queen Juliana of the Netherlands in 1952 in New York. In 1954, Queen Juliana attended a performance during Graham's second European tour: an unprecedented success for American diplomacy in Europe.

13 Not only was Eleanor Roosevelt at the forefront of American cultural diplomatic efforts, but she also broadened the scope of public diplomacy by speaking on behalf of civil organizations and causes. This as we have seen in Dario Fazzi's essay was effective in the issue of pacifism in the inter-war years. As Raffaela Baritono contends, this form of public diplomacy, 'diplomacy from below', was a trademark of Mrs. Roosevelt's approach to transnational relations post-second world war. ER's transatlantic relations were "bi-univocal and open to a whole world context" and enabled her to act as "bridge between political power and civil society", making her the "conscience of the world".

14 The final two essays in this collection explore communication techniques used by Eleanor Roosevelt to encourage the public to assume joint responsibility with political leaders to create a better world and foster the ideals of western democracy. Media formed an integral part therefore of her public and cultural diplomacy strategies. Sara Polak explains how Eleanor Roosevelt's astute use of media also enabled ER to informally and indirectly expand FDR's influence during his life into the domestic sphere and entertainment sections of mass media during, and maintain it in the public conscience after his death. Moreover, this ability to render FDR's autofabrication more powerful aided her own autofabrication: that of someone who created a public image of modesty while becoming a household name "with unprecedented authority throughout the Western world".

15 While Polak concentrates on Eleanor Roosevelt's writing, in the final essay Anya Luscombe examines the way ER used radio a means of soft power. Mrs. Roosevelt recognized that the intimate medium of radio gave her direct entry into the homes of listeners all over the world. A strong supporter of the Voice of America, Mrs. Roosevelt took part in many of its broadcasts. Addressing audiences in Europe and beyond not only gave her a platform to promote the United Nations and world peace and encourage active citizen participation in achieving those goals, but also allowed her as a Cold War Warrior to both voice and shape the American view of transatlantic relations.

16Eleanor Roosevelt's proclivity for humanitarianism and her unmatched global popularity then, make her one of the most outstanding examples of American public diplomats. While her public diplomacy efforts have not necessarily been consistent, they have social, cultural and political legacies and as such the authors here would argue have left their enduring imprint on transatlantic relations as a whole. 


\section{NOTES}

i. This is what David Armitage defines as Circum-Atlantic history, i.e. the transnational history of the Atlantic world, see David Armitage, "Three Concepts of Atlantic History," in David Armitage, Michael Braddick (eds.), The British Atlantic World, 1500-1800 (New York: Palgrave, 2002), 15. See also, among the others, Marco Mariano (ed.), Defining the Atlantic Community: Culture, Intellectuals, and Policies in the Mid-Twentieth Century (New York: Routledge 2010), Kiran Klaus Patel, Kenneth Weisbrode (eds.), European Integration and the Atlantic Community in the 1980s (New York: Cambridge University Press, 2013), Grzegorz Kosc, Clara Juncker, Sharon Monteith, Britta Waldschmidt-Nelson (eds.), The Transatlantic Sixties: Europe and the United States in the Counterculture Decade (Bielefeld: Transcript, 2013).

edited by Jeroen van Dongen (ed.), Cold War Science and the Transatlantic Circulation of Knowledge (Leiden and Boston: Brill, 2015),

edited by

ii. See Report of the Advisory committee on Cultural diplomacy. US Department of State, in http://www.state.gov/documents/organization/54374.pdf, accessed 23 January 2016.

iii. Memo Acheson to Truman. President's Secretary's Files. 3563, April 11, 1952. Harry S. Truman Library. GaleNet

iv. Pilgrim's dinner, April 12, 1948 (unaired speech. Paley Center audio, New York, accessed 2 April 2015)

v. Allida Black, Casting her own shadow (New York: Columbia University Press, 1996).

vi. Eleanor Roosevelt Papers Project, George Washington University, https://www.gwu.edu/ erpapers/abouteleanor/erbiography.cfm Accessed 25 March 2016.

vii. "Eleanor Roosevelt and the Universal Declaration of Human Rights", FDR Library, http:// www.fdrlibrary.marist.edu/library/pdfs/sears.pdf Accessed 25 March 2016.

viii. See Joseph Rezek, "What We Need from Transatlantic Studies," in American Literary History, vol. 26, no. 4 (Winter 2014), 791-803.

\section{AUTHORS}

\section{ANYA LUSCOMBE}

University College Roosevelt

DARIO FAZZI

Roosevelt Study Center 